\title{
Cathepsin B activity has a crucial role in the developmental competence of bovine cumulus-oocyte complexes exposed to heat shock during in vitro maturation
}

\author{
A Z Balboula ${ }^{1,2,+}, \mathrm{K}$ Yamanaka $^{1, \neq}, \mathrm{M} \mathrm{Sakatani}^{1}, \mathrm{M} \mathrm{Kawahara}^{3}$, A O Hegab $^{2, \S}, \mathrm{S}$ M Zaabel $^{2}$ \\ and $M$ Takahashi ${ }^{1,3}$ \\ ${ }^{1}$ Kyushu Okinawa Agricultural Research Center, National Agriculture and Food Research Organization (NARO), \\ 2421 Suya, Kumamoto 861-1192, Japan, ${ }^{2}$ Theriogenology Department, Faculty of Veterinary Medicine, Mansoura \\ University, 35516 Mansoura, Egypt and ${ }^{3}$ Department of Animal Science, Hokkaido University, Kita 9, Nishi 9, \\ Sapporo, Hokkaido 060-8589, Japan
}

Correspondence should be addressed to M Takahashi at Department of Animal Science, Hokkaido University; Email: mmasashi@anim.agr.hokudai.ac.jp

${ }^{+}$A Z Balboula is now at Department of Genetics, Rutgers, State University of New Jersey, Piscataway, New Jersey 08854, USA

${ }^{\ddagger} \mathrm{K}$ Yamanaka is now at Faculty of agriculture, Saga University, Saga City, Saga 840-8502, Japan

${ }^{\S}$ A O Hegab is now at Biology Department, Faculty of Science, Taif University, Taif, Kingdom of Saudi Arabia (KSA)

\begin{abstract}
Cathepsin B was found to be correlated inversely with the quality of bovine oocytes and embryos. The aims of this study were to evaluate i) the relationship between heat shock during in vitro maturation (IVM) of bovine cumulus-oocyte complexes (COCs) and cathepsin B activity in relation to apoptosis and ii) the effect of supplementation of cathepsin B inhibitor (E-64) during IVM of heat-shocked COCs on embryonic development. After IVM at $38.5{ }^{\circ} \mathrm{C}$ for $22 \mathrm{~h}$ (control group) or at $38.5^{\circ} \mathrm{C}$ for $5 \mathrm{~h}$ followed by $41^{\circ} \mathrm{C}$ for $17 \mathrm{~h}$ (heat shock group) either with or without $1 \mu \mathrm{M}$ E-64, activities and protein expression of cathepsin B and caspase 3 were evaluated as well as TUNEL staining. After IVF, developmental rate, total cell number, and the percentage of apoptotic cells in blastocysts were evaluated on day 8 (day 0, IVF day). Heat-shocked IVM COCs showed significantly high activities and expressions of both cathepsin B, and caspase 3 accompanied by a significant increase in number of TUNEL-positive cells. Addition of E-64 significantly decreased the activities of cathepsin B and caspase 3, and TUNEL-positive cells in heat-shocked IVM COCs. Moreover, addition of $1 \mu \mathrm{M} \mathrm{E-64} \mathrm{during} \mathrm{IVM} \mathrm{under} \mathrm{heat}$ shock conditions significantly improved both developmental competence and quality of the produced embryos. These results indicate that heat shock induction of cathepsin B is associated with apoptosis of COCs, and inhibition of cathepsin B activity can improve the developmental competence of heat-shocked COCs during IVM.
\end{abstract}

Reproduction (2013) 146 407-417

\section{Introduction}

In tropical and subtropical areas, elevated ambient temperature in summer is considered one of the most important factors responsible for reduced fertility in farm animals (Ealy et al. 1993). Heat stress may reduce the fertility of dairy cows by the direct effects of elevated maternal temperatures that compromise the ovum as it matures in preparation for fertilization. Conception rates in dairy cattle were $10-20 \%$ in the hot summer vs $50-55 \%$ in cooler seasons in Florida (Badinga et al. 1985). In particular, elevated ambient temperatures sufficient to raise rectal temperatures $\geq 41.0^{\circ} \mathrm{C}$ during estrus were previously shown to increase the proportion of degenerated or retarded embryos recovered after insemination of superovulated Holstein heifers (Putney et al. 1989). A similar reduction in embryonic development has been reported when bovine cumulusoocyte complexes (COCs) were exposed to heat shock at $41.0^{\circ} \mathrm{C}$ during in vitro maturation (IVM) (Edwards \& Hansen 1996, Lawrence et al. 2004, Roth \& Hansen 2004a).

Although the precise mechanisms of reduced conception rates and low embryo viability during the hot season are not yet clear, the detrimental influence of heat stress might be partially responsible. Exposing bovine oocytes to heat shock during IVM impairs intracellular protein synthesis (Edwards \& Hansen 1996), cortical granule translocation to the oolemma (Payton et al. 2004), and proper rearrangement of the cytoskeleton elements (Roth \& Hansen 2005). Moreover, Ju et al. (2005) reported that heat shock affects polymerization and de-polymerization of meiotic spindle microtubules 
in bovine oocytes leading to chromosomal dispersion and ultimately death of the cell may occur (Streffer 1984). However, the effect of heat shock on cumulus cells cannot be ignored. The cumulus cells are essential in the acquisition of developmental competence of mammalian oocytes through stimulating glutathione synthesis (de Matos et al. 1997, Gilchrist et al. 2004, Makabe et al. 2006) and protecting against the oxidative damage during IVM (Tatemoto et al. 2000). Exposing immature porcine COCs to heat shock disrupted the meiotic process and was accompanied by a significant increase in number of TUNEL-positive cells in the surrounding cumulus cells (Yuan et al. 2008). Thus, heat shock can disrupt the developmental competence of COCs by affecting both the oocyte itself and its surrounding cumulus cells.

These detrimental effects of heat shock on COCs during IVM could be controlled by different pathways (Ju \& Tseng 2004, Roth \& Hansen 2005, Wang et al. 2009). Oxidative stress is one of these pathways that is associated with an increase in reactive oxygen species either in vivo (Roth et al. 2008) or in vitro (Lawrence et al. 2004). Nevertheless, the administration of antioxidants did not fully rescue the developmental competence, suggesting a contribution of other factors (Roth \& Hansen 2004a, Soto \& Smith 2009).

It has been demonstrated that heat shock compromised the developmental competence of bovine oocytes through induction of apoptotic cascade (Roth \& Hansen 2004a, Soto \& Smith 2009). Heat shock during bovine oocyte maturation disrupts mitochondrial membrane permeability (Nabenishi et al. 2012) and stimulates group II caspase activation (Roth \& Hansen 2004a), which is probably key to apoptosis induction as evidenced by TUNEL-positive cells. However, the complete mechanism of heat shock-induced apoptosis through mitochondrial membrane damage and caspase activation in COCs is still unrevealed.

Cathepsin B, a lysosomal cysteine protease, was found to induce the apoptotic pathway through activating initiator caspases rather than executioner caspases either directly or indirectly in mouse fibroblast L929 cells (Vancompernolle et al. 1998). Cathepsin B can activate caspases indirectly through induction of mitochondrial membrane degradation, leading to translocation of apoptosis inducing components from the mitochondria into the cytosol (Bossy-Wetzel et al. 1998). This translocation promoted the activation of caspase-3, leading to the completion of apoptosis (Krippner et al. 1996, Adachi et al. 1997, Scaffidi et al. 1998). Furthermore, cathepsin B increases in poor-quality bovine oocytes and embryos, which is associated with low developmental competence, than in good-quality ones. Supplementation of the IVM medium with cathepsin B inhibitor (E-64) improved the developmental competence of bovine COCs possibly by regulation of the apoptotic pathway (Bettegowda et al. 2008, Balboula et al. 2010a, 2010b). However, there is no available data about the possible role of cathepsin B during oocyte maturation and subsequent development under heat shock condition. In this study, we investigated the possible role of cathepsin B in heat shock-induced apoptosis during IVM of bovine COCs and the effect of its inhibition on the subsequent developmental competence of heat-shocked oocytes.

\section{Materials and methods \\ Oocyte collection and IVM}

This study was carried out during the cold seasons (NovemberJune) where the average ambient temperature was $11.58{ }^{\circ} \mathrm{C}$. Holstein ovaries were collected from a local abattoir. The ovaries were washed several times in a sterile saline containing $100 \mathrm{IU} / \mathrm{ml}$ penicillin and $100 \mu \mathrm{g} / \mathrm{ml}$ streptomycin (Nacalai Tesque, Kyoto, Japan).

COCs were aspirated from follicles $(2-6 \mathrm{~mm}$ in diameter) using a 19-gauge needle attached to a $10 \mathrm{ml}$ syringe and washed three times in TCM-199 (Gibco) containing 5\% (v/v) FCS (Gibco). Fifty COCs were matured in a $500 \mu \mathrm{l}$ drop of TCM-199 supplemented with 5\% FCS, follicle-stimulating hormone (0.02 IU/ml; Denka, Kawasaki, Tokyo, Japan), estradiol-17 $\beta$ (1 $\mu \mathrm{g} / \mathrm{ml}$; Sigma-Aldrich), and gentamicin $(10 \mu \mathrm{g} / \mathrm{ml}$, Sigma-Aldrich) covered with mineral oil (Sigma-Aldrich) at $38.5{ }^{\circ} \mathrm{C}$ for $22 \mathrm{~h}$ (control group) or at $38.5^{\circ} \mathrm{C}$ for $5 \mathrm{~h}$ followed by $41{ }^{\circ} \mathrm{C}$ for $17 \mathrm{~h}$ (heat shock group) in a humidified atmosphere of $5 \% \mathrm{CO}_{2}$ in air.

Cumulus cells were cultured in DMEM (Gibco) plus 5\% FCS at $38.5{ }^{\circ} \mathrm{C}$ in humidified atmosphere of $5 \% \mathrm{CO}_{2}$ for $24 \mathrm{~h}$ according to Tani et al. (2000). The cumulus cells were detached, counted, and cultured on slide chambers (5000 cells/well) at $38.5^{\circ} \mathrm{C}$ for $22 \mathrm{~h}$ (control group) or at $38.5^{\circ} \mathrm{C}$ for $5 \mathrm{~h}$ followed by $41^{\circ} \mathrm{C}$ for $17 \mathrm{~h}$ (heat shock group) in a humidified atmosphere of $5 \% \mathrm{CO}_{2}$ in air.

\section{IVF}

Frozen semen (from two fertility-proven bulls) was thawed by immersing the straw in warm water $\left(37^{\circ} \mathrm{C}\right)$ for $20 \mathrm{~s}$. Spermatozoa were washed by centrifugation $(800 \mathrm{~g}$ for $10 \mathrm{~min}$ ) in $90 \%(\mathrm{v} / \mathrm{v})$ Percoll solution (GE Healthcare Bio-Sciences AB, Stockholm, Sweden). After removing the supernatant, the pellet was diluted with IVF-100 solution (Research Institute for the Functional Peptides, Yamagata, Japan) and further centrifugation was applied at $800 \mathrm{~g}$ for $5 \mathrm{~min}$. The spermatozoa pellet was diluted with IVF-100 to prepare the final sperm cell concentration of $5-10 \times 10^{6} / \mathrm{ml}$.

After maturation, COCs were washed three times with IVF-100 and then transferred into drops of sperm cell suspension (20 oocytes/100 $\mu \mathrm{l}$ drop) covered with mineral oil. Fertilization was carried out for $6 \mathrm{~h}$ at $38.5^{\circ} \mathrm{C}$ in a humidified atmosphere of $5 \% \mathrm{CO}_{2}$ in air.

\section{In vitro culture}

After fertilization, cumulus cells were removed mechanically by pipetting in CR1aa medium (Rosenkrans et al. 1993) 
containing 5\% FCS. Presumptive zygotes were transferred to $50 \mu \mathrm{l}$ micro-drops (20-30 zygotes/drop) of CR1aa supplemented with 5\% FCS covered with mineral oil. Embryos were then cultured in a humidified atmosphere of $5 \% \mathrm{O}_{2}, 5 \% \mathrm{CO}_{2}$, and $90 \% \mathrm{~N}_{2}$ at $38.5{ }^{\circ} \mathrm{C}$ for 8 days.

\section{Detection of intracellular activity of cathepsin B and caspase 3}

Detection of cathepsin B in oocytes, COCs, or cultured cumulus cells as well as caspase 3 activity in oocytes was carried out after IVM using Magic red detection kit for cathepsin B (MR-RR) 2 (Immunochemistry Technologies, LLC, $\mathrm{P}$ 6133, Bloomington, MN, USA) and caspase 3 (DEVD) $)_{2}$ (Immunochemistry Technologies, LLC, kit no. 935) according to the manufacturer's protocols. In brief, 20-30 matured oocytes were stained in $500 \mu \mathrm{l}$ Dulbecco's PBS (DPBS) with $2 \mu \mathrm{l}$ reaction mix in a humidified atmosphere of $5 \% \mathrm{CO}_{2}$ at $38.5{ }^{\circ} \mathrm{C}$ for $20 \mathrm{~min}$. To detect nuclei, bisbenzimide (Hoechst 33342; Sigma-Aldrich) was added in a concentration of $25 \mu \mathrm{g} / \mathrm{ml}$ and incubated in the same culture condition for further 5-10 min. After rinsing in DPBS with $3 \mathrm{mg} / \mathrm{ml}$ polyvinylpyrrolidone (PVP, Sigma-Aldrich), the stained oocytes were mounted onto a glass slide and observed under the fluorescence microscope (TE-300, Nikon, Tokyo, Japan). An excitation filter of $365 \mathrm{~nm}$ was used for observing the nuclei of cumulus cells (blue), while an excitation filter of $590 \mathrm{~nm}$ was applied for detection of intracellular cathepsin B activity (red) as well as caspase 3 (red). The images were captured and fluorescence emission intensity (pixels) was analyzed by Image Software (National Institutes of Health, Bethesda, MD, USA). In brief, the defined cells were selected and the red cytoplasmic background was excluded by setting the threshold above the background level. This threshold was maintained at the same level for all analyzed images. The average of total fluorescence emissions (pixels) was calculated.

\section{Lysosomal localization and stability assessment}

To label lysosomes, denuded oocytes after IVM were incubated with 75 nM LysoTracker red (Molecular Probes, L-7528, Eugene, OR, USA) for $30 \mathrm{~min}$ at $37^{\circ} \mathrm{C}$. After rinsing in PBS with $3 \mathrm{mg} / \mathrm{ml}$ PVP, the stained oocytes were mounted onto a glass slide and observed under the fluorescence microscope with a $590 \mathrm{~nm}$ excitation filter. The fluorescent images were captured and analyzed by Image Software. In brief, the defined cells were selected and the red cytoplasmic background was excluded by setting the threshold above the background level. This threshold was maintained at the same level for all analyzed images. The average size of the lysosomal dots (red) was calculated.

\section{TUNEL}

A TUNEL assay kit was used to assess the presence of apoptotic cells (In Situ Cell Death Detection Kit, Roche Applied Science) in in vitro matured COCs and day 8 blastocysts. In vitro matured COCs or blastocysts were fixed in $4 \%(\mathrm{w} / \mathrm{v})$ paraformaldehyde solution ( $\mathrm{pH} 7.4$ ) for 15-30 min, rinsed twice in PBS, and then permeabilized in PBS with $0.5 \%$ Triton- $X$ for
20 min followed by twice washing for $10 \mathrm{~min}$ in PBS with $3 \mathrm{mg} / \mathrm{ml}$ PVP. The fragmented DNA ends of the cells were labeled with fluorescein-dUTP for $60 \mathrm{~min}$ at $37^{\circ} \mathrm{C}$. After incubation, the COCs and blastocysts were washed three times in PBS with $3 \mathrm{mg} / \mathrm{ml}$ PVP for $5 \mathrm{~min}$ each, followed by mounting onto glass slides using mounting solution containing DAPI, Vectashield with DAPI (Vector Laboratories, Burlingame, CA, USA). The fluorescence of fragmented DNA ends was detected using an excitation filter of $488 \mathrm{~nm}$ by fluorescent microscope (Nikon TE-300). Total cell number was also recorded at the same time.

\section{Western blot analysis}

In vitro matured COCs (sets of five) were lysed in 1\% SDS (Nacalai Tesuque), $1 \% \beta$-mercaptoethanol (Nacalai Tesuque), $20 \%$ glycerol (Nacalai Tesuque), and $50 \mathrm{mM}$ Tris- $\mathrm{HCl}$ (pH 6.8) and denatured at $95{ }^{\circ} \mathrm{C}$ for $5 \mathrm{~min}$. Sample solutions were separated by electrophoresis in 5-20\% gradient SDS-polyacrylamide precast gels (Wako Junyaku, Tokyo, Japan). Pre-stained marker proteins with known molecular mass (range: 14-200 kDa) were run simultaneously as standards. The electrophoretically separated proteins were transferred onto PVDF membrane using an iBlot Gel transfer System (Invitrogen). The membranes were incubated in PVDF blocking reagent (B1080501, Toyobo, Tokyo, Japan) for $1 \mathrm{~h}$ and then washed three times in Tris-buffered saline and Tween 20 (TBS-T) at room temperature. Membranes were incubated with primary antibodies for cathepsin B (1:1000 dilution; Mouse MAB to cathepsin B, cat no. ab58802, Abcam), caspase 3 (1:1000 dilution, Rabbit polyclonal antibody, cat no. AAP113, Stressgen, Ann Arbor, MI, USA), and $\beta$-actin (1:3000 dilution, cat no. G043, Applied Biological Materials, Inc., Richmond, BC, Canada) at $4{ }^{\circ} \mathrm{C}$ overnight. After three washes with TBS-T, membranes were incubated with a HRP-labeled anti-mouse IgG secondary antibody (1:25 000 dilution, cat no. NA931, GE Healthcare, Buckinghamshire, UK) or anti-rabbit IgG (1:25 000 dilution, cat no. RPN430, GE Healthcare) at room temperature for $1 \mathrm{~h}$. Primary and secondary antibodies were diluted with immunoreaction enhancer, Can Get Signal (Toyobo). Membranes were washed extensively with TBS-T before detection of bound antibodies using the ECL-Plus Western Blotting Detection System (GE Healthcare) as per the manufacturer's instructions. Chemiluminescent signals were captured by ChemiDoc System (BioRad) and analyzed using a software (Quantity One, Bio-Rad).

\section{Experimental design}

Experiment 1: the effect of heat shock during IVM on cathepsin $B$ activity, caspase 3 activity, and lysosomal localization and destabilization in bovine COCs:

COCs and cultured cumulus cells were randomly allocated to three groups and matured at $38.5^{\circ} \mathrm{C}$ for $22 \mathrm{~h}$ (control), $38.5^{\circ} \mathrm{C}$ for $5 \mathrm{~h}$ followed by $41^{\circ} \mathrm{C}$ for $17 \mathrm{~h}$ (heat shock), and $38.5^{\circ} \mathrm{C}$ for $5 \mathrm{~h}$ followed by $41^{\circ} \mathrm{C}$ for $17 \mathrm{~h}$ with $1 \mu \mathrm{M}$ E-64 (cathepsin B inhibitor, cat no. E3132, Sigma-Aldrich) (heat shock plus E-64). The effect of heat shock on the activity of cathepsin B was evaluated in denuded oocytes as well as in COCs and/or in 
cumulus cells. Caspase 3 activity and lysosomal localization were also investigated in denuded oocytes. Denuded oocytes were obtained by removing the surrounded cumulus cells mechanically with $0.1 \%$ hyaluronidase.

Experiment 2: effect of heat shock during IVM on protein expression of cathepsin B and caspase 3 in bovine COCs:

To investigate whether the increase in cathepsin B and caspase 3 activities during heat shock is accompanied by increasing amounts of cathepsin B and caspase 3 proteins, both cathepsin $\mathrm{B}$ and caspase 3 protein expression were compared between in vitro matured COCs and heat-shocked COCs matured either with or without $1 \mu \mathrm{M}$ E-64 using western blot analysis.

Experiment 3: effect of heat shock during IVM on TUNEL apoptosis of bovine COCs:

To elucidate the apoptotic effect of heat shock and the protective effect of E-64, TUNEL staining as an apoptosis indicator was performed and compared between heat-shocked COCs and control ones. Moreover, the effect of cathepsin B inhibitor $(1 \mu \mathrm{M}$ E-64) on heat shock apoptosis was also investigated.

Experiment 4: effect of E-64 on developmental competence of COCs compromised by heat shock during IVM:

Bovine COCs were randomly allocated to treatments in groups of 50 (control, heat shock, and heat shock plus E-64) and then cultured in the maturation medium. After $22 \mathrm{~h}$ of maturation, COCs were fertilized and cultured. Developmental competence was assessed by cleavage and blastocyst rates on days 2 and 8 respectively. Total cell number and TUNEL were also assessed on day 8 blastocysts.

\section{Statistical analysis}

Each experiment was replicated at least three times. The data were expressed as means \pm S.E.M. The statistical significance of differences was analyzed by both Student's t-test and ANOVA using StatView, version 5.0 (Abacus Conceptus, Berkeley, CA, USA). When the ANOVA test yielded a $P$ value $<0.05$, the data were analyzed using the Fisher post-hoc test.

\section{Results}

The effect of heat shock on cathepsin B activity, caspase 3 activity, and lysosome localization in in vitro matured oocytes and cultured cumulus cells

As shown in Fig. 1A and B, cathepsin B activity in bovine oocytes was significantly increased by heat shock $(P<0.05)$. On the other hand, addition of $1 \mu \mathrm{M}$ E-64 to the IVM medium during heat shock significantly diminished the increase in cathepsin B activity.

Moreover, control oocytes showed normal punctuate lysosomal staining (Fig. 1C and D). After exposure to heat shock conditions, lysosomal aggregation, and release of lysosomal contents into the cytosol increased
(Fig. 1C and D). The addition of E-64 to the IVM medium during heat shock could not rescue the abnormal localization and aggregation of the lysosomes (Fig. 1C and D).

Furthermore, cytoplasmic caspase 3 activity was clearly increased upon exposure to heat shock (Fig. 1E and $F$ ). We then investigated whether caspase 3 is involved in the cathepsin B pathway or not. Caspase 3 activity was significantly decreased by addition of E-64 during heat shock (Fig. 1E and F).

The same results for cathepsin B activity were obtained in COCs and cultured cumulus cells. Under heat shock condition, both cumulus cells of heatshocked COCs (Fig. 2A) and cultured cumulus cells (Fig. 2B) showed higher cathepsin B activity than control COCs and such activity was decreased by addition of $1 \mu \mathrm{M}$ E-64 to the IVM medium.

\section{The effect of heat shock during IVM on protein expression of cathepsin B and caspase 3}

Western blot analysis clearly revealed a significant increase $(P<0.05)$ in both cathepsin B and caspase 3 expressions in heat-shocked COCs than in control COCs (Fig. 3). Moreover, the addition of $1 \mu \mathrm{M} \mathrm{E}-64$ to the IVM medium significantly decreased the expression of caspase 3 but not cathepsin B (Fig. 3).

\section{The effect of heat shock during IVM on the TUNEL-positive cells of IVM COCS}

To confirm the compromising effect of heat shock during IVM on the apoptotic status of bovine COCs, TUNEL staining was evaluated after incubation of bovine COCs at $41{ }^{\circ} \mathrm{C}$ for $17 \mathrm{~h}$ during IVM. The percentage of TUNEL-positive cells was obviously higher in heatshocked COCs than in control COCs (Fig. 4). The addition of E-64 to the IVM medium significantly decreased $(P<0.05)$ the heat-shock-induced apoptosis of cumulus cells (Fig. 4).

\section{Inhibition of cathepsin $B$ activity improves the developmental competence of bovine COCs compromised by heat shock during IVM}

Heat shock during IVM decreased the blastocyst rate significantly $(P<0.05)$. On the other hand, addition of $1 \mu \mathrm{M}$ E-64 to the maturation medium significantly $(P<0.05)$ improved the blastocyst rate under heat shock conditions (Table 1). In contrast the cleavage rate did not vary significantly among groups (Table 1 ). Exposure of COCs to heat shock during IVM decreased the quality of the embryos produced as evidenced by the significant decrease $(P<0.05)$ in total cell number and increase $(P<0.05)$ in number of TUNEL-positive cells (Table 2 and Fig. 5). Interestingly, addition of $1 \mu \mathrm{M}$ E-64 to IVM medium could rescue the quality yielding a significant 

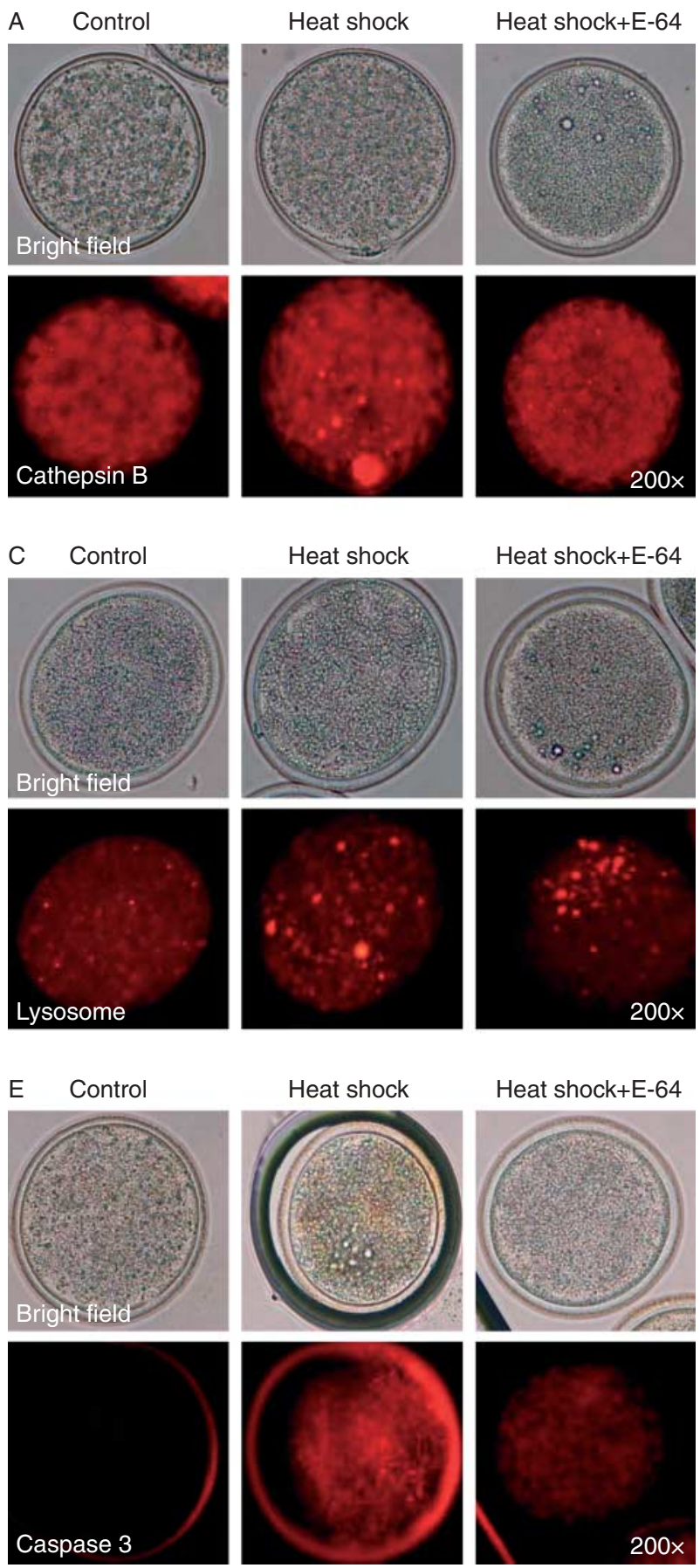
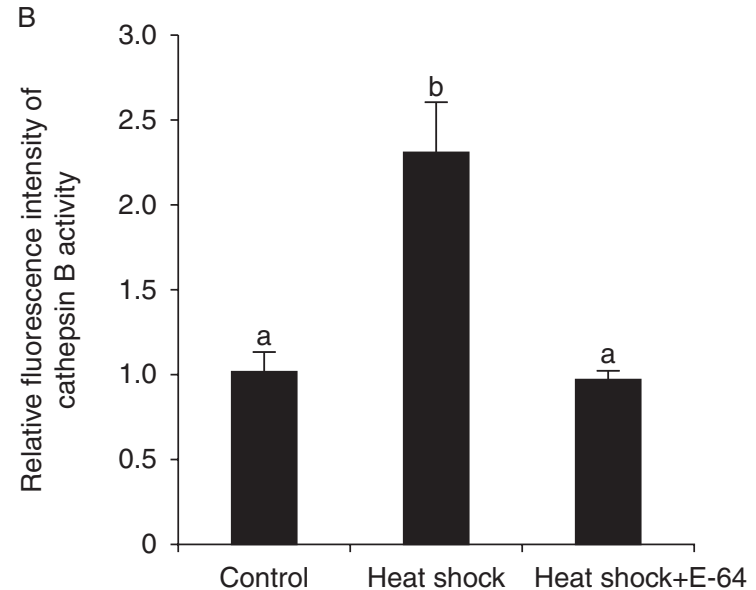

D

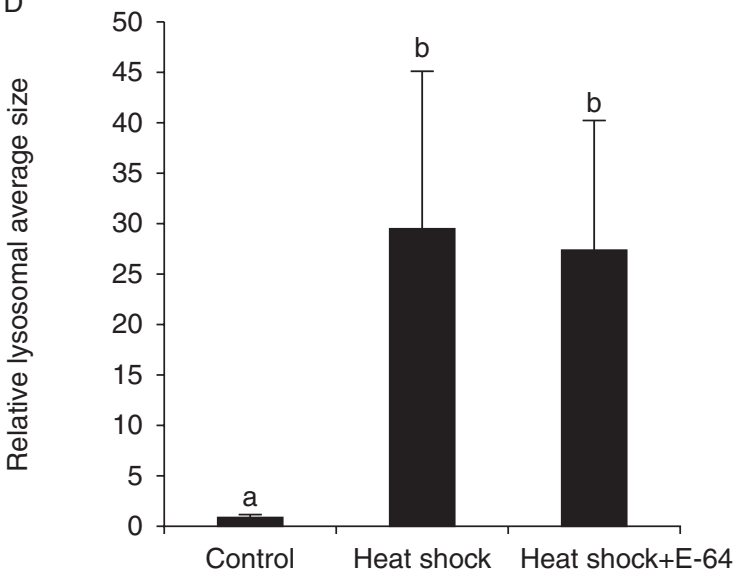

$\mathrm{F}$

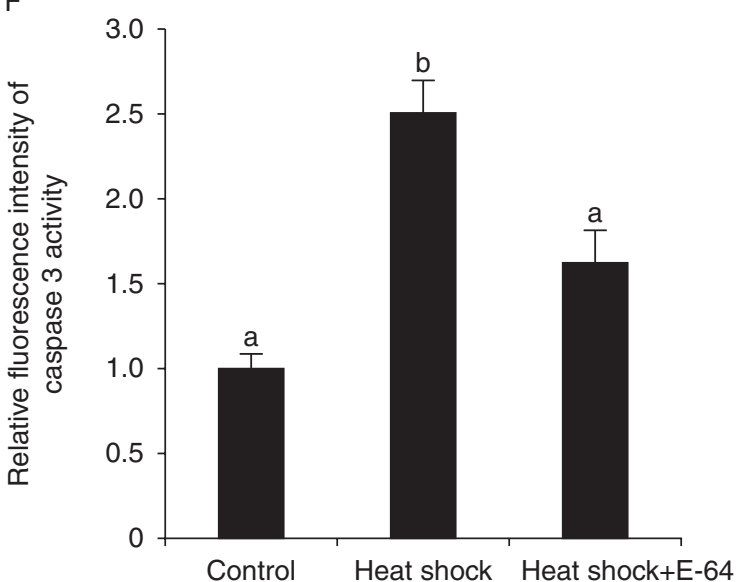

Figure $1 \mathrm{Effect}$ of heat shock during IVM on intracellular activity of cathepsin $\mathrm{B}$, and caspase 3 , and lysosomal localization in bovine denuded oocytes. Bovine COCs were incubated at $38.5^{\circ} \mathrm{C}$ for $22 \mathrm{~h}$ (control) or at $38.5^{\circ} \mathrm{C}$ for $5 \mathrm{~h}$ followed by $41{ }^{\circ} \mathrm{C}$ for $17 \mathrm{~h}$ either with (heat shock plus E- 64 ) or without (heat shock) $1 \mu \mathrm{M} \mathrm{E}-64$. IVM COCs were denuded and examined for cathepsin B activity, caspase 3 activity, and lysosome localization. (A) Intracellular localization of the active form of cathepsin B was detected as red fluorescent dots using a 590 nm excitation filter. (B) Quantification of the fluorescence intensity of cathepsin B activity. (C) Lysosomes were detected using a $590 \mathrm{~nm}$ excitation filter as red fluorescent dots. (D) Quantification of the lysosomal average size. (E) Intracellular localization of caspase 3 activity was detected as diffuse red fluorescence signal in oocytes' cytoplasm using a $590 \mathrm{~nm}$ excitation filter. (F) Quantification of the fluorescence intensity of caspase 3 activity. Values with different letters across treatments differ significantly, $P<0.05 . n=3$ replicates, original magnification $200 \times$. 
A
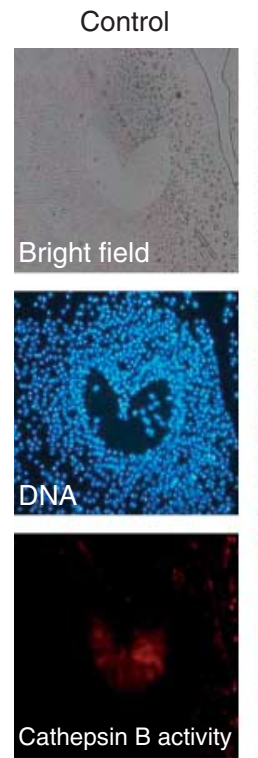

C
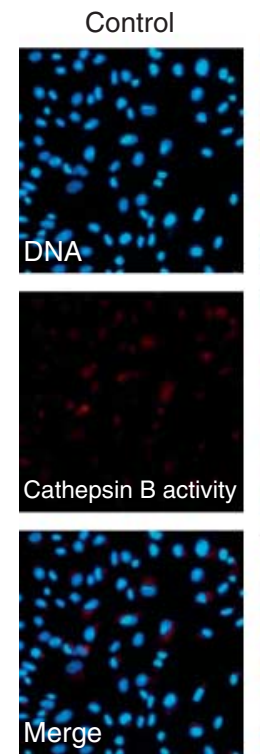

Heat shock
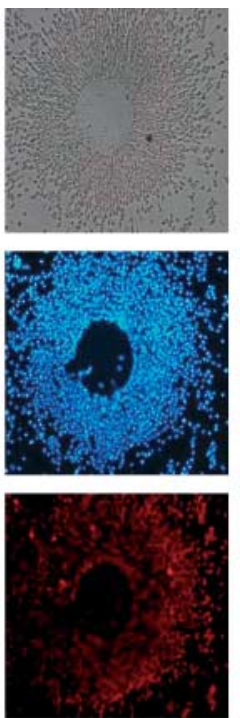

Heat shock
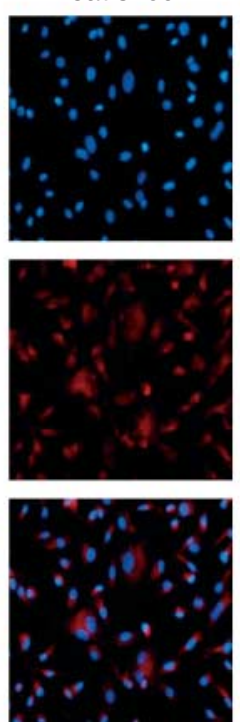
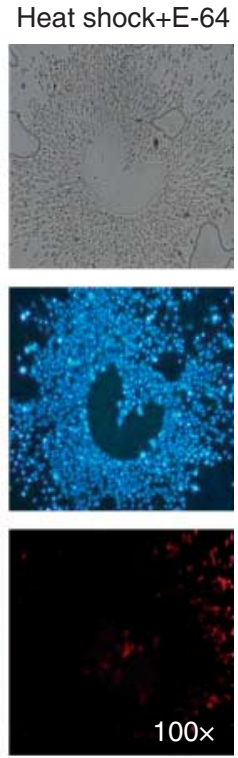

Heat shock+E-64
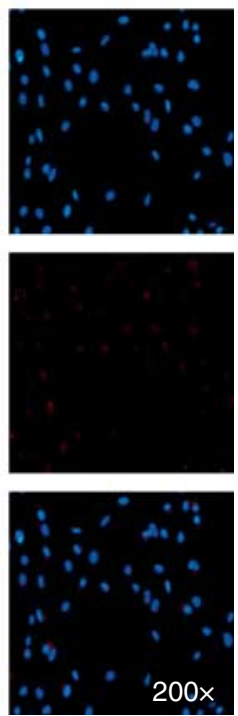

B
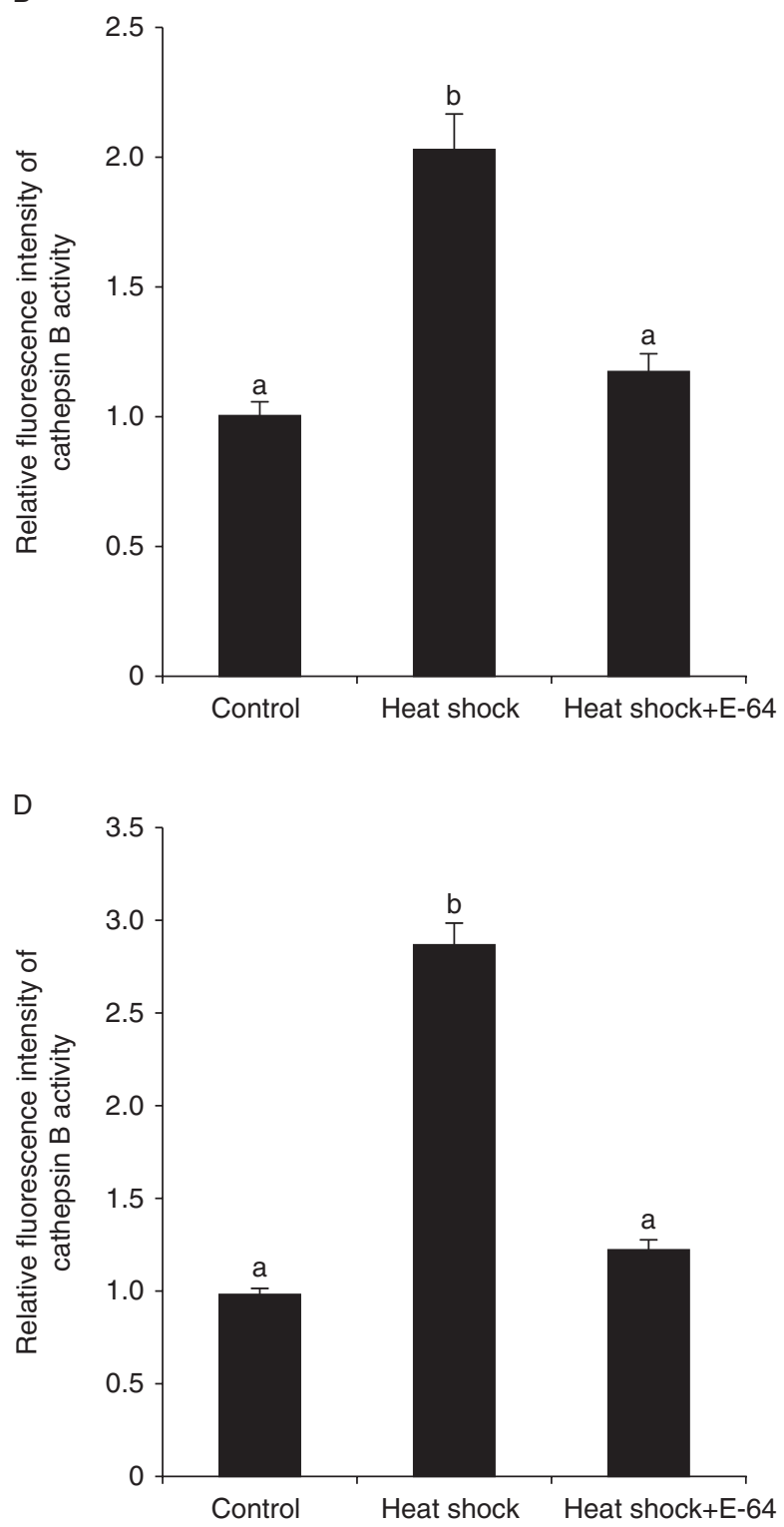

Figure 2 Effect of heat shock during IVM on cathepsin B activity in bovine COCs and cultured cumulus cells. Bovine COCs and cultured cumulus cells were incubated at $38.5^{\circ} \mathrm{C}$ for $22 \mathrm{~h}$ (control) or at $38.5^{\circ} \mathrm{C}$ for $5 \mathrm{~h}$ followed by $41^{\circ} \mathrm{C}$ for $17 \mathrm{~h}$ either with (heat shock plus $\mathrm{E}-64$ ) or without (heat shock) $1 \mu \mathrm{M} \mathrm{E-64}$. The nuclei of cells were stained with DAPI. Cathepsin B activity was detected as red fluorescent dots in COCs (A) and cultured cumulus cells (C) using a $590 \mathrm{~nm}$ excitation filter. (B and D) Quantification of the fluorescence intensity of cathepsin B activity in COCs and cumulus cells. Values with different letters across treatments differ significantly, $P<0.05 . n=3$ replicates, original magnification $200 \times$ in cumulus cells and $100 \times$ in COCs.

$(P<0.05)$ increase in total cell number and decrease in number of TUNEL-positive cells (Table 2 and Fig. 5).

\section{Discussion}

Our results showed that i) heat shock during IVM compromises oocyte developmental competence due to the increase in cathepsin B activity either in denuded oocytes or their surrounding cumulus cells and the increase in the number of TUNEL-positive cells in COCs and ii) inhibition of cathepsin B activity during IVM with heat shock of bovine oocytes improves developmental competence and quality of the embryos produced by decreasing the number of TUNEL-positive cells in COCs and blastocysts.

Apoptosis was found to play a critical role in the harmful effect of thermal stress during mammalian oocyte maturation (Roth \& Hansen 2004b, 2005, Yuan et al. 2008, Soto \& Smith 2009). Our result showing a significant increase in the number of TUNEL-positive 

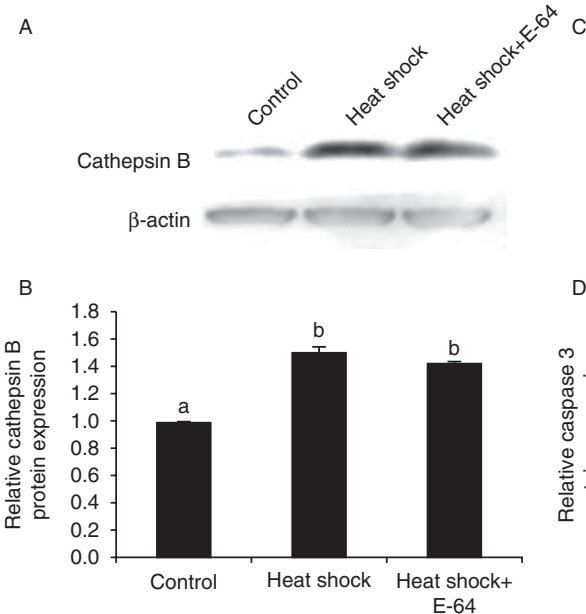

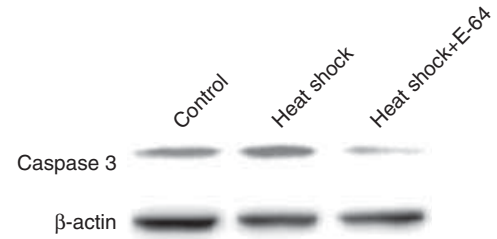

D

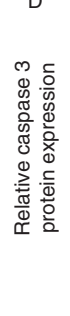

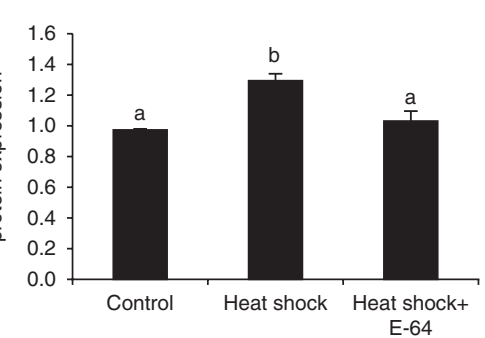

Figure 3 Protein expression of cathepsin B and caspase 3 in bovine COCs by western blot. (A and B) Cathepsin B protein expression and relative expression levels (three replicates) in control, heat-shocked COCs either with or without E-64. (C and D) Caspase 3 protein expression and relative expression levels ( $n=5$ replicates) respectively in relation to heat shock either with or without E-64. Values with different letters across treatments differ significantly, $P<0.05$. cells in heat-shocked COCs is in agreement with previous reports (Roth \& Hansen 2004a, Soto \& Smith 2009). They found that heat shock during oocyte maturation was closely related to the apoptotic response, which, in turn, led to disruption of the oocyte's capacity to support early embryonic development following fertilization. These results clearly showed that apoptotic pathway can be considered to be an important factor for impairing the developmental competence of bovine oocytes compromised by heat shock during IVM.

Cathepsin B is a lysosomal cysteine protease that plays an important role in the degradation of intracellular tissue proteins in lysosomes (Barrett \& Kirschke 1981, Szpaderska \& Frankfater 2001). Cathepsin B localizes in various types of cells including liver, ovaries, and COCs (Olstein \& Liener 1983, Oksjoki et al. 2001,
A
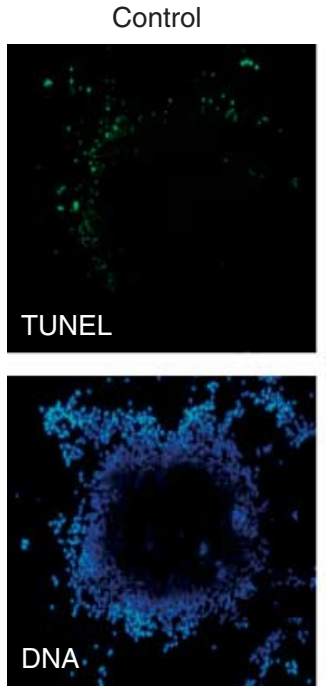

Heat shock
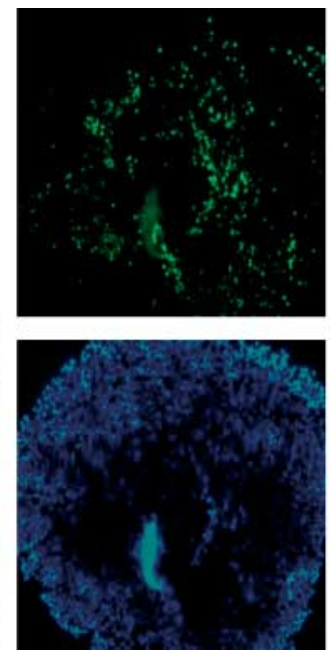

Heat shock+E-64
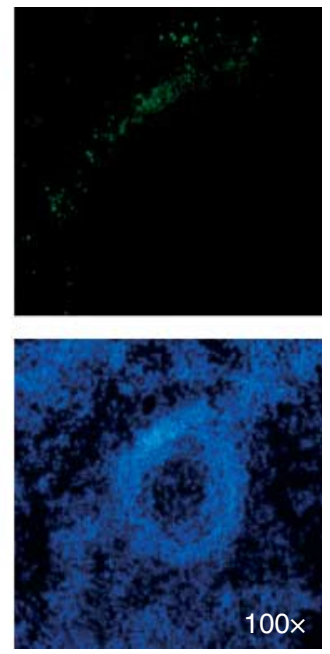

B

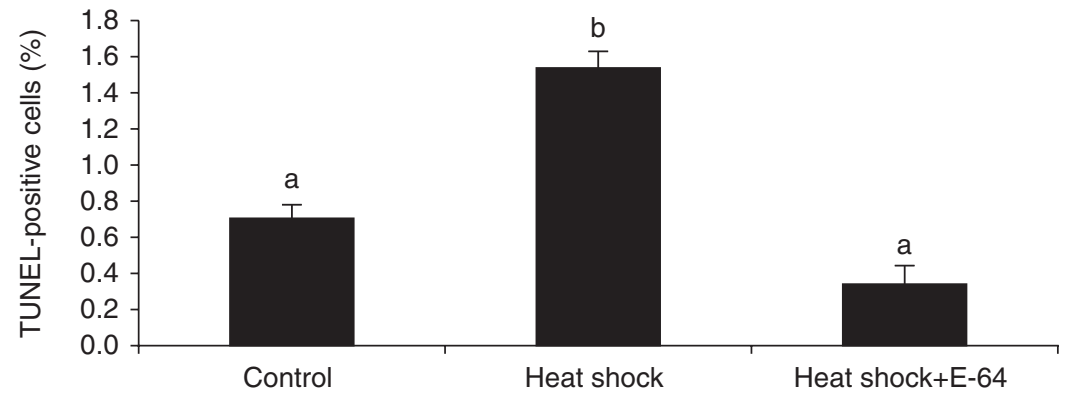

Figure 4 Effect of heat shock during IVM on the apoptotic status of bovine COCs. Apoptotic status was compared between control COCs and heat-shocked COCs either with or without E-64. (A) TUNEL staining (green) was used to detect cumulus cell apoptosis while DAPI staining (blue) was used for DNA detection (B)

Quantification of (A) showing the percentages of TUNEL-positive cells. Values with different letters across treatments differ significantly, $P<0.05 . n=3$ replicates. Original magnification $100 \times$. 
Table 1 Effect of E-64 on developmental competence of COCs compromised by heat shock during in vitro maturation.

\begin{tabular}{lccc}
\hline & $\begin{array}{c}\text { No. of } \\
\text { COCs }\end{array}$ & $\begin{array}{c}\text { Cleavage } \\
\text { rate }(\%)\end{array}$ & $\begin{array}{c}\text { Blastocyst } \\
\text { rate }(\%)\end{array}$ \\
\hline Control & 209 & $75.15 \pm 7.9$ & $37.34 \pm 2.7$ \\
Heat shock & 202 & $72.52 \pm 6.1$ & $23.11 \pm 3.0^{*}$ \\
Heat shock+E-64 & 204 & $72.99 \pm 4.9$ & $33.43 \pm 3.8$ \\
\hline
\end{tabular}

Data pooled from six replicates. Values marked with asterisks differ significantly $(P<0.05)$ from other values in the same column.

Bettegowda et al. 2008), suggesting that cathepsin B has many cell functions. Bettegowda et al. (2008) first reported that cumulus cells of low developmental competence oocytes showed higher expression of cathepsin B mRNA than those of high developmental competence oocytes (Bettegowda et al. 2008). Moreover, our previous studies clearly showed that cathepsin B activity is inversely correlated with the quality of bovine COCs and embryos by the higher activity and protein expression of cathepsin B in poor-quality in vitro matured oocytes and embryos than in good-quality ones (Balboula et al. 2010a, 2010b). Furthermore, cathepsin B was found to impair the oocyte and embryo developmental competence by possible stimulation of the apoptotic pathway (Balboula et al. 2010a, 2010b). In this study, the significant decrease in TUNEL apoptosis in heat-shocked bovine COCs after the addition of cathepsin B inhibitor (E-64) to the IVM medium clearly showed that cathepsin B has one of the key roles in inducing apoptosis during heat shock of bovine COCs.

Cathepsin B purified from lysosomal protease has the ability to induce apoptosis in somatic cells by activating initiator caspases rather than executioner caspases (Vancompernolle et al. 1998). These observations are in agreement with our hypothesis that cathepsin B, in bovine COCs, plays an important role in heat shock-induced apoptosis and that caspase 3 is possibly one of its downstream targets. To test our hypothesis, both cathepsin B and caspase 3 along with lysosomal localization were compared after exposure of bovine COCs to heat shock during IVM either with or without E-64. Our results showing a significant increase in cathepsin B and caspase 3 during heat shock clearly revealed that cathepsin B and caspase 3 play a crucial role in the apoptotic cascade.

Cathepsin B can activate caspases through induction of mitochondrial membrane degradation, a condition known as permeability transition, which leads to the release of proapoptotic factors into the cytosol (BossyWetzel et al. 1998, Boya et al. 2003). This finding is supported by the fact that mitochondria play a crucial role in regulation of cell death pathways (Wang 2001, Droga-Mazovec et al. 2008). The rate of apoptosis in mammalian oocytes was decreased after microinjection of mitochondria purified from non-apoptotic granulosa cells (Perez et al. 2000). Regardless of the effect of cathepsin B on caspases activation, cathepsin B itself could induce nuclear apoptosis when added to a reconstituted system containing isolated nuclei in the absence of cytosolic caspase 3 (Ishisaka et al. 1998, Antunes et al. 2001).

Lysosomes are membrane-bound dynamic organelles that are indispensable for endocytosis, phagocytosis, and autophagy (Eskelinen et al. 2003). Exogenous stresses such as oxidative stress in somatic cells can induce lysosomal destabilization and leakage of its destructive components (Zdolsek et al. 1990, Brunk et al. 1995). Moreover, inhibiting general trafficking of the lysosomes in cancer cells resulted in their aggregation and destabilization of their membrane permeability with subsequent release of their contents to the cytosol, where they can trigger caspase-mediated apoptosis (Cardoso et al. 2009). Our results showed that control IVM oocytes have normal punctuate lysosomal staining with barely seen activities of either cathepsin B or caspase 3 . On the other hand, heat shock exposure caused a defect in lysosomal membrane permeability followed by lysosomal aggregation and release of lysosomal cathepsin B into the cytosol. The addition of E-64 to the IVM medium during heat shock could not rescue the abnormal localization of the lysosomes but significantly decreased the activity of both cathepsin B and caspase 3. Moreover, addition of E-64 could decrease caspase 3 expression level but not cathepsin B protein expression. This stability of cathepsin B protein against E-64 could be explained by the fact that E-64 has the ability to inhibit the activity of cathepsin B but not the protein expression. These results support our hypothesis that increasing cathepsin B activity can induce apoptosis in bovine oocytes, at least in part, through stimulation of caspase 3. Moreover, these results are consistent with the findings of Guicciardi et al. (2000) who reported that hepatocytes from cathepsin B knockout mice are resistant to TNF $\alpha$-induced apoptosis (Foghsgaard et al. 2001) and gives further explanation for the results of Roth and Hansen who concluded that heat shock induces apoptosis by stimulating group II caspases in bovine oocytes (Roth \& Hansen 2004a).

Although cumulus cells have been known to be very resistant, our results clearly showed that bovine cumulus cells are highly affected by heat shock as evidenced by significant increase in both cathepsin B activity and TUNEL apoptosis. This finding is supported by the results

Table 2 Effect of E-64 treatment during in vitro maturation under heat shock condition on total cell number and apoptotic status of day 8 blastocysts.

\begin{tabular}{lclc}
\hline & $\begin{array}{c}\text { No. of } \\
\text { blastocysts }\end{array}$ & $\begin{array}{c}\text { Total } \\
\text { cell no. }\end{array}$ & $\begin{array}{c}\text { TUNEL-positive } \\
\text { cells }(\%)\end{array}$ \\
\hline Control & 28 & $162.30 \pm 8.1$ & $2.49 \pm 0.3$ \\
Heat shock & 24 & $127.11 \pm 10.7^{*}$ & $8.24 \pm 1.7^{*}$ \\
Heat shock+E-64 & 26 & $158.26 \pm 10.0$ & $2.54 \pm 0.6$ \\
\hline
\end{tabular}

Data pooled from four replicates. Values marked with asterisks differ significantly $(P<0.05)$ from other values in the same column. 

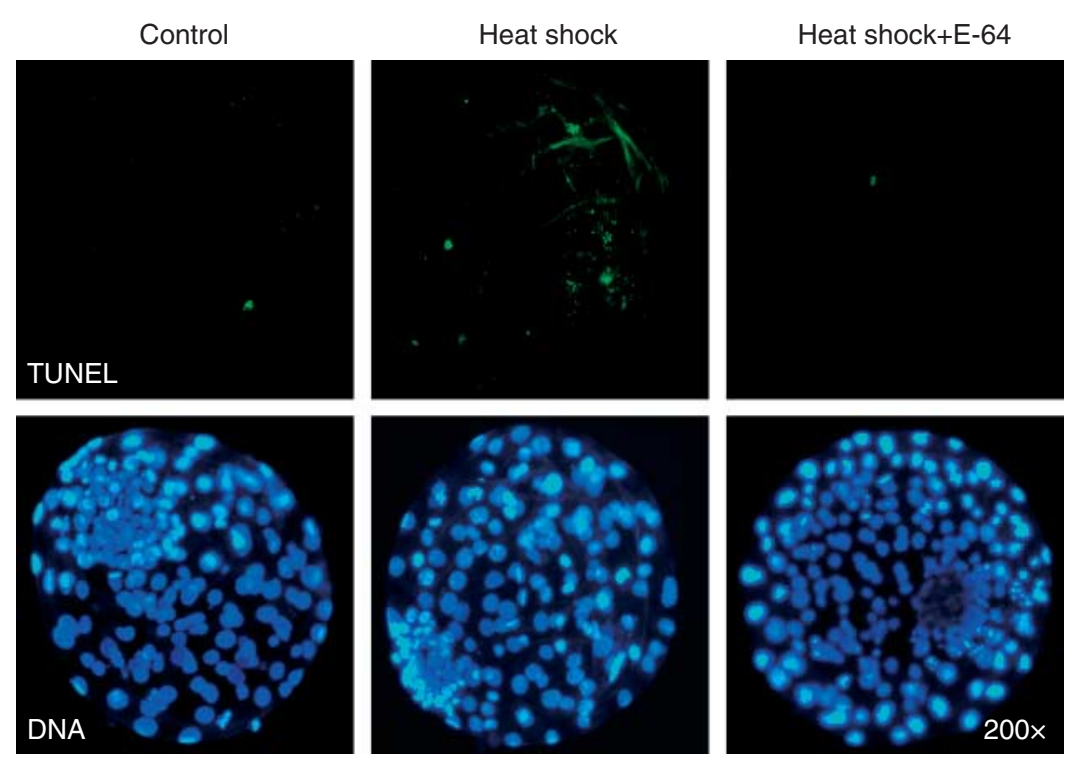

Figure 5 Effect of E-64 treatment during IVM under heat shock condition on total cell number and apoptotic status of day 8 blastocysts after IVF and culture. TUNEL staining (green) was used to detect apoptotic cells while DAPI staining (blue) was used for DNA detection. $n=4$ replicates, number of blastocysts examined $=78$. of Yuan et al. (2008) who concluded that heat shock causes apoptosis of porcine cumulus cells, which contribute to maturation failure of porcine oocytes. Bidirectional communication between the oocyte and cumulus cells occurs throughout follicular development (Sirard et al. 2006) and is essential for the acquisition of developmental competence of mammalian oocytes. Moreover, cumulus cells stimulate glutathione synthesis in bovine oocytes (de Matos et al. 1997, Gilchrist et al. 2004, Makabe et al. 2006) and help to protect against the damage induced by oxidative stress during IVM (Tatemoto et al. 2000). In addition, it is well known that cumulus cells play a crucial role in the follicular differentiation process, providing optimal conditions for oocyte growth, fertilization, and subsequent development (Adashi 1994). Thus, it is plausible that any disruption in the cumulus cells surrounding the oocyte can be responsible for a reduction in oocyte developmental competence under heat shock conditions. Exposure of bovine oocytes or cumulus cells to heat shock during IVM would stimulate cathepsin B to be leaked from lysosomes that were partially damaged. It is likely that this cathepsin B leakage together with its increased activity induces mitochondrial permeability transition followed by activation of caspases, thereby inducing the apoptotic pathway.

E-64 is an irreversible nontoxic cysteine protease inhibitor. The nontoxicity of E-64 makes it a good template for drugs to treat diseases where cysteine proteases are the primary cause, such as rheumatoid arthritis (Yoshifuji et al. 2005), muscular dystrophy (Tamai et al. 1986), and Alzheimer diseases (Trinchese et al. 2008). Moreover, E-64 has no compromising effect on embryo development, embryos that were produced from E-64-treated oocytes resulted in normal pregnancies (A Balboula \& M Takahashi 2013, our unpublished data). According to the working concentrations determined for E-64, $1 \mu \mathrm{M}$ E-64 was added to the IVM medium. We found that heat shock during IVM significantly reduced the blastocyst rate. On the other hand, maturation (A Balboula \& M Takahashi 2013, our unpublished data) and cleavage rates did not vary significantly. Addition of $1 \mu \mathrm{M}$ E-64 significantly improved the blastocyst rate compared with the heat shock group. This result suggests that there is a strong relationship between cathepsin $\mathrm{B}$ activity during heat shock and the developmental competence of bovine oocytes and that inhibition of cathepsin B activity can be a means of improving developmental rates.

Average total cell number and the number of TUNEL apoptotic cells are considered valuable tools for evaluating the quality of pre-implantation embryos (Hardy 1997, Fouladi-Nashta et al. 2005, Matsuura et al. 2010, Su et al. 2011). In heat-shocked embryos, the apoptosis may arise in a wave as a result of the heat shock pulse during IVM leading to a decrease in total cell number of day 8 blastocysts. In this study, addition of E-64 during heat shock significantly increased total cell number of day 8 blastocysts compared with the heat shock group. Moreover, addition of E-64 significantly decreased the percentages of TUNEL-positive cells in day 8 blastocysts compared with the heat shock group. Our results clearly showed that controlling cathepsin B activity during heat shock can alter blastocyst quality by both increasing the total cell number and decreasing TUNEL-positive cells. Thus, these results clearly support a promising role of cathepsin B inhibitors under heat shock conditions in improving embryo development and quality.

Although E-64 inhibits some cysteine proteinases including cathepsin B, it does not inhibit cathepsins S, Z, and K (Barrett et al. 1982). Moreover, only cathepsins $\mathrm{B}, \mathrm{S}, \mathrm{Z}$, and $\mathrm{K}$ showed negative association with bovine oocyte developmental competence in microarray experiments (Patel et al. 2007). Furthermore, addition of 
CA-074, a specific inhibitor of cathepsin B, had the same improving effect on the developmental competence of bovine COCs compromised by heat shock (A Balboula \& M Takahashi 2013, our unpublished data). Given the previous data, we suggest that E-64 improves developmental competence by inhibiting cathepsin B.

In conclusion, the present results implicate cathepsin B activity as one of the possible pathways that are responsible for heat shock-induced apoptosis in bovine COCs. Moreover, controlling the activity of cathepsin B can be a useful approach for blocking heat stress-induced apoptosis in mammalian oocytes with subsequent improvement in female fertility.

\section{Declaration of interest}

The authors declare that there is no conflict of interest that could be perceived as prejudicing the impartiality of the research reported.

\section{Funding}

This research was supported by National Agriculture Research Organization, Japan, and grant-aid for scientific research from JSPS (KAKENHI, 24580439).

\section{Acknowledgements}

The authors thank Ms E Kawano and Ms Teramoto for assistance with this research. The authors also thank the Kumamoto Meat Trading Center and Kumamoto prefectural Meat Inspection Office for collecting bovine ovaries.

\section{References}

Adachi S, Cross AR, Babior BM \& Gottlieb RA $1997 \mathrm{Bcl}-2$ and the outer mitochondrial membrane in the inactivation of cytochrome $c$ during Fasmediated apoptosis. Journal of Biological Chemistry 272 21878-21882. (doi:10.1074/jbc.272.35.21878)

Adashi EY 1994 Endocrinology of the ovary. Human Reproduction 9 815-827. (doi:10.1093/humrep/9.suppl_2.36)

Antunes F, Cadenas E \& Brunk UT 2001 Apoptosis induced by exposure to a low steady-state concentration of $\mathrm{H}_{2} \mathrm{O}_{2}$ is a consequence of lysosomal rupture. Biochemical Journal 356 549-555. (doi:10.1042/0264-6021: 3560549)

Badinga L, Collier RJ, Thatcher WW \& Wilcox CJ 1985 Effects of climatic and management factors on conception rate of dairy cattle in subtropical environment. Journal of Dairy Science 68 78-85. (doi:10.3168/jds. S0022-0302(85)80800-6)

Balboula AZ, Yamanaka K, Sakatani M, Hegab AO, Zaabel SM \& Takahashi M 2010a Cathepsin B activity is related to the quality of bovine cumulus oocyte complexes and its inhibition can improve their developmental competence. Molecular Reproduction and Development 77 439-448. (doi:10.1002/mrd.21164)

Balboula AZ, Yamanaka K, Sakatani M, Hegab AO, Zaabel SM \& Takahashi M 2010b Intracellular cathepsin B activity is inversely correlated with the quality and developmental competence of bovine preimplantation embryos. Molecular Reproduction and Development $\mathbf{7 7}$ 1031-1039. (doi:10.1002/mrd.21250)

Barrett AJ \& Kirschke H 1981 Cathepsin B, cathepsin H, and cathepsin L. Methods in Enzymology 80 535-561.
Barrett AJ, Kembhavi AA, Brown MA, Kirschke H, Knight CG, Tamai M \& Hanada K 1982 L-trans-Epoxysuccinyl-leucylamido(4-guanidino)butane (E-64) and its analogues as inhibitors of cysteine proteinases including cathepsins B, H and L. Biochemical Journal 201 189-198.

Bettegowda A, Patel OV, Lee KB, Park KE, Salem M, Yao J, Ireland JJ \& Smith GW 2008 Identification of novel bovine cumulus cell molecular markers predictive of oocyte competence: functional and diagnostic implications. Biology of Reproduction 79 301-309. (doi:10.1095/ biolreprod.107.067223)

Bossy-Wetzel E, Newmeyer DD \& Green DR 1998 Mitochondrial cytochrome $c$ release in apoptosis occurs upstream of DEVD-specific caspase activation and independently of mitochondrial transmembrane depolarization. EMBO Journal 17 37-49. (doi:10.1093/emboj/17.1.37)

Boya P, Andreau K, Poncet D, Zamzami N, Perfettini JL, Metivier D, Ojcius DM, Jaattela M \& Kroemer G 2003 Lysosomal membrane permeabilization induces cell death in a mitochondrion-dependent fashion. Journal of Experimental Medicine 197 1323-1334. (doi:10.1084/jem.20021952)

Brunk UT, Zhang H, Dalen H \& Ollinger K 1995 Exposure of cells to nonlethal concentrations of hydrogen peroxide induces degenerationrepair mechanisms involving lysosomal destabilization. Free Radical Biology \& Medicine 19 813-822. (doi:10.1016/0891-5849(95)02001-Q)

Cardoso CM, Groth-Pedersen L, Hoyer-Hansen M, Kirkegaard T, Corcelle E, Andersen JS, Jaattela M \& Nylandsted J 2009 Depletion of kinesin 5B affects lysosomal distribution and stability and induces perinuclear accumulation of autophagosomes in cancer cells. PLOS ONE 4 e4424. (doi:10.1371/journal.pone.0004424)

Droga-Mazovec G, Bojic L, Petelin A, Ivanova S, Romih R, Repnik U, Salvesen GS, Stoka V, Turk V \& Turk B 2008 Cysteine cathepsins trigger caspase-dependent cell death through cleavage of bid and antiapoptotic Bcl-2 homologues. Journal of Biological Chemistry 283 19140-19150. (doi:10.1074/jbc.M802513200)

Ealy AD, Drost M \& Hansen PJ 1993 Developmental changes in embryonic resistance to adverse effects of maternal heat stress in cows. Journal of Dairy Science 76 2899-2905. (doi:10.3168/jds.S0022-0302(93)77629-8)

Edwards JL \& Hansen PJ 1996 Elevated temperature increases heat shock protein 70 synthesis in bovine two-cell embryos and compromises function of maturing oocytes. Biology of Reproduction 55 341-346. (doi:10.1095/biolreprod55.2.341)

Eskelinen EL, Tanaka Y \& Saftig P 2003 At the acidic edge: emerging functions for lysosomal membrane proteins. Trends in Cell Biology $\mathbf{1 3}$ 137-145. (doi:10.1016/S0962-8924(03)00005-9)

Foghsgaard L, Wissing D, Mauch D, Lademann U, Bastholm L, Boes $M$, Elling F, Leist $\mathbf{M}$ \& Jaattela M 2001 Cathepsin B acts as a dominant execution protease in tumor cell apoptosis induced by tumor necrosis factor. Journal of Cell Biology 153 999-1010. (doi:10.1083/jcb.153.5.999)

Fouladi-Nashta AA, Alberio R, Kafi M, Nicholas B, Campbell KH \& Webb R 2005 Differential staining combined with TUNEL labelling to detect apoptosis in preimplantation bovine embryos. Reproductive Biomedicine Online 10 497-502. (doi:10.1016/S1472-6483(10)60827-9)

Gilchrist RB, Ritter LJ \& Armstrong DT 2004 Oocyte-somatic cell interactions during follicle development in mammals. Animal Reproduction Science 82-83 431-446. (doi:10.1016/j.anireprosci.2004.05.017)

Guicciardi ME, Deussing J, Miyoshi H, Bronk SF, Svingen PA, Peters C, Kaufmann SH \& Gores GJ 2000 Cathepsin B contributes to TNF- $\alpha$-mediated hepatocyte apoptosis by promoting mitochondrial release of cytochrome $c$. Journal of Clinical Investigation 106 1127-1137. (doi:10.1172/JCI9914)

Hardy K 1997 Cell death in the mammalian blastocyst. Molecular Human Reproduction 3 919-925. (doi:10.1093/molehr/3.10.919)

Ishisaka R, Utsumi T, Yabuki M, Kanno T, Furuno T, Inoue M \& Utsumi K 1998 Activation of caspase-3-like protease by digitonin-treated lysosomes. FEBS Letters 435 233-236. (doi:10.1016/S0014-5793(98)01080-1)

Ju JC \& Tseng JK 2004 Nuclear and cytoskeletal alterations of in vitro matured porcine oocytes under hyperthermia. Molecular Reproduction and Development 68 125-133. (doi:10.1002/mrd.20054)

Ju JC, Jiang S, Tseng JK, Parks JE \& Yang X 2005 Heat shock reduces developmental competence and alters spindle configuration of bovine oocytes. Theriogenology 64 1677-1689. (doi:10.1016/j.theriogenology.2005.03.025)

Krippner A, Matsuno-Yagi A, Gottlieb RA \& Babior BM 1996 Loss of function of cytochrome $C$ in Jurkat cells undergoing fas-mediated apoptosis. Journal of Biological Chemistry 271 21629-21636. (doi:10.1074/jbc.271.35.21629) 
Lawrence JL, Payton RR, Godkin JD, Saxton AM, Schrick FN \& Edwards JL 2004 Retinol improves development of bovine oocytes compromised by heat stress during maturation. Journal of Dairy Science $\mathbf{8 7}$ 2449-2454. (doi:10.3168/jds.S0022-0302(04)73368-8)

Makabe S, Naguro T \& Stallone T 2006 Oocyte-follicle cell interactions during ovarian follicle development, as seen by high resolution scanning and transmission electron microscopy in humans. Microscopy Research and Technique 69 436-449. (doi:10.1002/jemt.20303)

de Matos DG, Furnus CC \& Moses DF 1997 Glutathione synthesis during in vitro maturation of bovine oocytes: role of cumulus cells. Biology of Reproduction 57 1420-1425. (doi:10.1095/biolreprod57.6.1420)

Matsuura K, Hayashi N, Takiue C, Hirata R, Habara T \& Naruse K 2010 Blastocyst quality scoring based on morphologic grading correlates with cell number. Fertility and Sterility 94 1135-1137. (doi:10.1016/ j.fertnstert.2009.11.003)

Nabenishi H, Takagi S, Kamata H, Nishimoto T, Morita T, Ashizawa K \& Tsuzuki Y 2012 The role of mitochondrial transition pores on bovine oocyte competence after heat stress, as determined by effects of cyclosporin A. Molecular Reproduction and Development 79 31-40. (doi:10.1002/mrd.21401)

Oksjoki S, Soderstrom M, Vuorio E \& Anttila L 2001 Differential expression patterns of cathepsins B, H, K, L and S in the mouse ovary. Molecular Human Reproduction 7 27-34. (doi:10.1093/molehr/7.1.27)

Olstein AD \& Liener IE 1983 Comparative studies of mouse liver cathepsin $\mathrm{B}$ and an analogous tumor thiol proteinase. Journal of Biological Chemistry 258 11049-11056.

Patel OV, Bettegowda A, Ireland JJ, Coussens PM, Lonergan P \& Smith GW 2007 Functional genomics studies of oocyte competence: evidence that reduced transcript abundance for follistatin is associated with poor developmental competence of bovine oocytes. Reproduction 133 95-106. (doi:10.1530/rep.1.01123)

Payton RR, Romar R, Coy P, Saxton AM, Lawrence JL \& Edwards JL 2004 Susceptibility of bovine germinal vesicle-stage oocytes from antral follicles to direct effects of heat stress in vitro. Biology of Reproduction 71 1303-1308. (doi:10.1095/biolreprod.104.029892)

Perez GI, Trbovich AM, Gosden RG \& Tilly JL 2000 Mitochondria and the death of oocytes. Nature 403 500-501. (doi:10.1038/35000651)

Putney DJ, Mullins S, Thatcher WW, Drost M \& Gross TS 1989 Embryonic development in superovulated dairy cattle exposed to elevated ambient temperatures between the onset of estrus and insemination. Animal Reproduction Science 19 37-51. (doi:10.1016/0378-4320(89)90045-6)

Rosenkrans CF Jr, Zeng GQ, MCNamara GT, Schoff PK \& First NL 1993 Development of bovine embryos in vitro as affected by energy substrates. Biology of Reproduction 49 459-462. (doi:10.1095/biolreprod49.3.459)

Roth Z \& Hansen PJ 2004a Involvement of apoptosis in disruption of developmental competence of bovine oocytes by heat shock during maturation. Biology of Reproduction 71 1898-1906. (doi:10.1095/ biolreprod.104.031690)

Roth Z \& Hansen PJ 2004b Sphingosine 1-phosphate protects bovine oocytes from heat shock during maturation. Biology of Reproduction $\mathbf{7 1}$ 2072-2078. (doi:10.1095/biolreprod.104.031989)

Roth Z \& Hansen PJ 2005 Disruption of nuclear maturation and rearrangement of cytoskeletal elements in bovine oocytes exposed to heat shock during maturation. Reproduction 129 235-244. (doi:10.1530/rep.1.00394)

Roth Z, Aroyo A, Yavin S \& Arav A 2008 The antioxidant epigallocatechin gallate (EGCG) moderates the deleterious effects of maternal hyperthermia on follicle-enclosed oocytes in mice. Theriogenology 70 887-897. (doi:10.1016/j.theriogenology.2008.05.053)

Scaffidi C, Fulda S, Srinivasan A, Friesen C, Li F, Tomaselli KJ, Debatin KM, Krammer PH \& Peter ME 1998 Two CD95 (APO-1/Fas) signaling pathways. EMBO Journal 17 1675-1687. (doi:10.1093/emboj/17.6.1675)
Sirard MA, Richard F, Blondin P \& Robert C 2006 Contribution of the oocyte to embryo quality. Theriogenology 65 126-136. (doi:10.1016/j. theriogenology.2005.09.020)

Soto P \& Smith LC 2009 BH4 peptide derived from Bcl-xL and Bax-inhibitor peptide suppresses apoptotic mitochondrial changes in heat stressed bovine oocytes. Molecular Reproduction and Development 76 637-646. (doi:10.1002/mrd.20986)

Streffer C 1984 Mechanism of heat injury. In Hyperthermic Oncology, Vol 2, pp 213-222. Ed J Overgaard. London: Taylor and Francis.

Su J, Wang Y, Li Y, Li R, Li Q, Wu Y, Quan F, Liu J, Guo Z \& Zhang Y 2011 Oxamflatin significantly improves nuclear reprogramming, blastocyst quality, and in vitro development of bovine SCNT embryos. PLOS ONE 6 e23805. (doi:10.1371/journal.pone.0023805)

Szpaderska AM \& Frankfater A 2001 An intracellular form of cathepsin B contributes to invasiveness in cancer. Cancer Research 61 3493-3500.

Tamai M, Matsumoto K, Omura S, Koyama I, Ozawa Y \& Hanada K 1986 In vitro and in vivo inhibition of cysteine proteinases by EST, a new analog of E-64. Journal of Pharmacobio-Dynamics 9 672-677. (doi:10.1248/bpb1978.9.672)

Tani T, Kato Y \& Tsunoda Y 2000 Developmental potential of cumulus cellderived culture frozen in a quiescent state after nucleus transfer. Theriogenology 53 1623-1629. (doi:10.1016/S0093-691X(00)00302-2)

Tatemoto H, Sakurai N \& Muto N 2000 Protection of porcine oocytes against apoptotic cell death caused by oxidative stress during In vitro maturation: role of cumulus cells. Biology of Reproduction 63 805-810. (doi:10.1095/biolreprod63.3.805)

Trinchese F, Fa M, Liu S, Zhang H, Hidalgo A, Schmidt SD, Yamaguchi $H$, Yoshii N, Mathews PM, Nixon RA et al. 2008 Inhibition of calpains improves memory and synaptic transmission in a mouse model of Alzheimer disease. Journal of Clinical Investigation 118 2796-2807. (doi:10.1172/JCl34254)

Vancompernolle $K$, Van Herreweghe F, Pynaert $G$, Van de Craen $M$, De Vos K, Totty N, Sterling A, Fiers W, Vandenabeele P \& Grooten J 1998 Atractyloside-induced release of cathepsin B, a protease with caspase-processing activity. FEBS Letters 438 150-158. (doi:10.1016/ S0014-5793(98)01275-7)

Wang X 2001 The expanding role of mitochondria in apoptosis. Genes and Development 15 2922-2933.

Wang JZ, Sui HS, Miao DQ, Liu N, Zhou P, Ge L \& Tan JH 2009 Effects of heat stress during in vitro maturation on cytoplasmic versus nuclear components of mouse oocytes. Reproduction 137 181-189. (doi:10.1530/REP-08-0339)

Yoshifuji H, Umehara H, Maruyama H, Itoh M, Tanaka M, Kawabata D, Fujii T \& Mimori T 2005 Amelioration of experimental arthritis by a calpain-inhibitory compound: regulation of cytokine production by $\mathrm{E}-64-\mathrm{d}$ in vivo and in vitro. International Immunology 17 1327-1336. (doi:10.1093/intimm/dxh311)

Yuan Y, Hao ZD, Liu J, Wu Y, Yang L, Liu GS, Tian JH, Zhu SE \& Zeng SM 2008 Heat shock at the germinal vesicle breakdown stage induces apoptosis in surrounding cumulus cells and reduces maturation rates of porcine oocytes in vitro. Theriogenology 70 168-178. (doi:10.1016/ j.theriogenology.2008.03.005)

Zdolsek JM, Olsson GM \& Brunk UT 1990 Photooxidative damage to lysosomes of cultured macrophages by acridine orange. Photochemistry and Photobiology 51 67-76. (doi:10.1111/j.1751-1097.1990.tb01685.x)

Received 27 April 2013

First decision 20 May 2013

Revised manuscript received 4 July 2013

Accepted 29 July 2013 